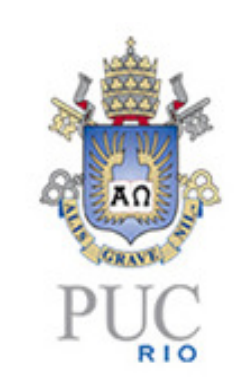

Igor Andrade Vidal Barbosa

\begin{abstract}
A Governamentalidade e o Desenvolvimento Internacional: Um Estudo de Caso do Acordo do Nordeste de 1962
\end{abstract}

Dissertação de Mestrado

Dissertação apresentada como requisito parcial para a obtenção do título de Mestre pelo Programa de Pós-Graduação em Relações Internacionais do Instituto de Relações Internacionais da PUC-Rio.

Orientador: Prof. João Franklin Abelardo

Pontes Nogueira

Rio de Janeiro

Novembro de 2010 
Igor Andrade Vidal Barbosa

\section{A Governamentalidade e o Desenvolvimento Internacional: Um Estudo de Caso do Acordo do Nordeste de 1962}

Dissertação apresentada como requisito parcial para a obtenção do título de Mestre pelo Programa de Pós-Graduação em Relações Internacionais do Instituto de Relações Internacionais da PUC-Rio. Aprovada pela Comissão Examinadora abaixo assinada.

Prof. João Franklin Abelardo Pontes Nogueira Orientador e Presidente Instituto de Relações Internacionais - PUC-Rio

Prof. Paulo Luiz Moreaux Lavigne Esteves Pontifícia Universidade Católica - PUC-Rio

Prof. Pedro Cláudio Cunca Brando Bocayuva Cunha Pontifícia Universidade Católica - PUC-Rio

Profa. Mônica Herz Vice Decana de Pós-Graduação do Centro de Ciências Sociais - PUC-Rio

Rio de Janeiro, 30 de novembro de 2010 
Todos os direitos reservados. É proibida a reprodução total ou parcial do trabalho sem autorização da universidade, do autor e do orientador

Igor Andrade Vidal Barbosa

Graduou-se em Relações Internacionais na Pontifícia Universidade Católica de Minas Gerais em 2007.

Ficha Catalográfica

Barbosa, Igor Andrade Vidal

A governamentalidade e o desenvolvimento internacional: um estudo de caso do Acordo do Nordeste de 1962 / Igor Andrade Vidal Barbosa ; orientador: João Franklin Abelardo Pontes Nogueira. 2010.

92 f. ; $30 \mathrm{~cm}$

Dissertação (mestrado)-Pontifícia Universidade Católica do Rio de Janeiro, Instituto de Relações Internacionais, 2010.

Inclui bibliografia

1. Relações internacionais - Teses. 2. Desenvolvimento internacional. 3. Governamentalidade. 4. Acordo do Nordeste. 5. SUDENE. 6. USAID. I. Nogueira, João Franklin Abelardo Pontes. II. Pontifícia Universidade Católica do Rio de Janeiro. Instituto de Relações Internacionais. III. Título. 


\section{Agradecimentos}

Ao meu orientador, João F. A. Pontes Nogueira, por toda a sua ajuda,

Ao CNPq e à PUC-Rio, pelos auxílios que me permitiram realizar esse mestrado,

Aos professores que participaram da Comissão examinadora,

A todos os professores e funcionários da PUC-Rio,

Aos meus pais e meus irmãos, que sempre serão a base de tudo na minha vida,

Aos amigos e familiares que me estimularam durante todo o trabalho e que estiveram presente de uma forma ou de outra,

À minha namorada, por ser exatamente do jeito que ela é,

A todos aqueles que de alguma forma foram essenciais, obrigado. 


\section{Resumo}

Barbosa, Igor; Nogueira, João Franklin Abelardo Pontes. A Governamentalidade e o Desenvolvimento Internacional: Um estudo de caso do Acordo do Nordeste de 1962. Rio de Janeiro, 2010. 92p. Dissertação de Mestrado - Instituto de Relações Internacionais, Pontifícia Universidade Católica do Rio de Janeiro.

A presente dissertação parte dos estudos de Michel Foucault acerca da governamentalidade com o intuito de compreender a temática do desenvolvimento internacional e, mais especificamente, o Acordo do Nordeste firmado em 1962 entre os Estados Unidos e o Brasil. Tal acordo surge da convergência de dois projetos distintos de desenvolvimento: a Operação Nordeste e a Aliança para o Progresso. Os anos iniciais do Acordo, contudo, foram marcados por uma série de divergências entre seus órgãos executores, quais sejam, a Superintendência do Desenvolvimento do Nordeste (SUDENE) e a Agência dos Estados Unidos para o Desenvolvimento Internacional (USAID). Tendo em vista a noção de que o desenvolvimento é um dispositivo de saber- poder que rearticula a maneira de se pensar sobre os limites temporais da Modernidade, situando a diferença entre sujeitos autônomos (civilizados) e não-autônomos (bárbaros) no contexto das normalidades e anormalidades que caracterizam uma população, adota-se como hipótese a idéia de que as discordâncias entre a SUDENE e a USAID representavam uma disputa política em torno da delimitação das categorias que definem os casos normais e anormais de desenvolvimento. Nesse sentido, trata-se também de uma disputa acerca dos próprios limites da Modernidade. Para indicar os principais pontos que compunham essa disputa, fez-se necessária a análise e a comparação das diferentes teorias que balizavam a Operação Nordeste e a Aliança para Progresso.

\section{Palavras- Chave}

Desenvolvimento Internacional; Governamentalidade; Acordo do Nordeste; SUDENE; USAID 


\section{Abstract}

Barbosa, Igor; Nogueira, João Franklin Abelardo Pontes (Advisor). Governmentality and International Development: a case study of the 1962 Northeast Agreement. Rio de Janeiro, 2010. 92p. MSc Dissertation Instituto de Relações Internacionais, Pontifícia Universidade Católica do Rio de Janeiro.

This dissertation uses Michel Foucault's study of governmentality with the purpose of understanding the issue of international development and, more specifically, the Northeast Agreement that was signed in 1962 between the United Stated and Brazil. This agreement results from the convergence of two distinct development projects: Operation Northeast and the Alliance for Progress. The initial years of the Agreement, however, were characterized by a number of disagreements between the two agencies that were responsible for its implementation, the Superintendency for the Development of the Northeast (SUDENE) and the United States Agency for International Development (USAID). Considering the notion that development is a dispositif of power and knowledge that refashions the way we think about the temporal limits of Modernity by placing the difference between autonomous (civilized) and dependent (barbarian) subjects in the context of the normalities and abnormalities that characterize any population, we assume the hypothesis that the discord between SUDENE and USAID represented a political dispute regarding the delimitation of categories that define the normal and abnormal cases of development. In this sense, it is also a dispute regarding the temporal limits of Modernity. The analysis and comparison of the different theories that guided Operation Northeast and the Alliance for Progress was necessary to indicate the main points of this dispute.

\section{Keywords}

International Development; Governmentality; Northeast Agreement; SUDENE; USAID 


\section{Sumário}

1. Introdução

2 Repensando o desenvolvimento 14

$\begin{array}{ll}2.1 \text { Introdução } & 14\end{array}$

$\begin{array}{ll}2.2 \text { As artes de governo } & 14\end{array}$

2.2.1. O liberalismo 19

2.2.2. O sistema internacional 25

$\begin{array}{ll}2.3 \text { Os dispositivos de saber poder } & 29\end{array}$

2.3.1. Sociedades demoníacas 30

2.3.2. A expansão da sociedade internacional 33

2.4 Conclusão 36

3. O Acordo do Nordeste e a Teoria da Modernização 37

$\begin{array}{ll}3.1 \text { Introdução } & 37\end{array}$

3.2 A Aliança para o Progresso e o Acordo do Nordeste 38

3.2.1. As divergências entre a USAID e a SUDENE 41

3.3 A teoria da modernização 49

3.4 Conclusão $\quad 56$

4 A Operação Nordeste e o pensamento desenvolvimentista 59

4.1 Introdução $\quad 59$

4.2 O "problema" do nordeste $\quad 59$

4.3 A Operação Nordeste e o desenvolvimento regional 62

4.3.1. A seca e a atuação do poder público 67

4.4 O pensamento desenvolvimentista ao nível nacional 71

4.4.1. Modernização ou conquista dos centros de decisão? 74

$\begin{array}{ll}4.5 \text { Conclusão } & 79\end{array}$

5. Conclusão 80

6. Referências Bibliográficas 82 
Anexos

1. O Acordo do Nordeste 
If I knew for a certainty that a man was coming to my house with a conscious design of doing me good, I should run for my life...For fear that I should get some of his good done to me.

(Thoreau apud Escobar, 2005) 